\title{
Transvalued Species in an African Forest
}

\author{
MELISSA J. REMIS* AND REBECCA HARDIN† \\ ${ }^{*}$ Department of Anthropology, Purdue University, 700 W. State Street, West Lafayette, IN 47907-2059, U.S.A., \\ email remis@purdue.edu \\ †Department of Anthropology and School of Natural Resources, University of Michigan, Ann Arbor, MI 48109-1107, U.S.A.
}

\begin{abstract}
We combined ethnographic investigations with repeated ecological transect surveys in the DzangaSangha Dense Forest Reserve (RDS), Central African Republic, to elucidate consequences of intensifying mixed use of forests. We devised a framework for transvaluation of wildife species, which means the valuing of species on the basis of their ecological, economic, and symbolic roles in human lives. We measured responses to bunting, tourism, and conservation of two transvalued species in RDS: elephants (Loxodonta cyclotis) and gorillas (Gorilla gorilla). Our methods included collecting data on encounter rates and habitat use on line transects. We recorded cross-cultural variation in ideas about and interactions with these species during participant observation of bunting and tourism encounters and ethnographic interviews with bunters, conservation staff, researchers, and tourists. Ecologically, gorillas used buman-modified landscapes successfully, and elephants were more vulnerable than gorillas to bunting. Economically, tourism and encounters with elephants and gorillas generated revenues and other benefits for local participants. Symbolically, transvaluation of species seemed to undergird competing institutions of forest management that could prove unsustainable. Nevertheless, transvaluation may also offer alternatives to existing social hierarchies, thereby integrating local and transnational support for conservation measures. The study of transvaluation requires attention to transnational flows of ideas and resources because they influence transspecies interactions. Cross-disciplinary in nature, transvalution of species addresses the political and economic challenges to conservation because it recognizes the varied human communities that shape the survival of wildlife in a given site. Transvaluation of species could foster more socially inclusive management and monitoring approaches attuned to competing economic demands, specific species behaviors, and buman practices at local scales.
\end{abstract}

Keywords: biological anthropology, central Africa, conservation anthropologies, conservation management, cultural anthropology, ecotourism, Gorilla gorilla, Loxodonta cyclotis, transvalued species, wildlife trade

Especies Sobrestimadas en un Bosque Africano

Resumen: Combinamos investigaciones etnográficas con muestreo de transectos ecológicos repetidos en la Reserva de Bosque Denso Dzanga-Sangha (RBD), República de África Central, para elucidar consecuencias de la intensificación del uso mixto de bosques. Diseñamos un marco de referencia para la sobrestimación de especies de vida silvestre, lo que significa la valoración de especies con base en su rol ecológico, económico y simbólico en las vidas humanas. Medimos las respuestas a la cacería, el turismo y la conservación de dos especies sobrestimadas en RBD: elefantes (Loxodonta cyclotis) y gorilas (Gorilla gorilla). Nuestros métodos incluyeron la recolección de datos sobre tasas de encuentro y uso de bábitat a lo largo de transectos lineales. Registramos la variación transcultural de las ideas sobre y las interacciones con estas especies durante la observación participativa de encuentros cinegéticos y turísticos y entrevistas etnográficas con cazadores, personal de conservación, investigadores y turistas. Ecológicamente, los gorilas exitosamente usaron paisajes modificados por humanos, y los elefantes fueron más vulnerables a la cacería que los gorilas. Económicamente, el turismo y encuentros con elefantes y gorilas generaron ingresos y otros beneficios para los participantes locales. Simbólicamente, la sobrestimación de especies aparentemente apoyó a instituciones de manejo de bosques que pudieran parecer no sustentables. Sin embargo, la sobrestimación también puede ofrecer alternativas a las jerarquías sociales existentes, por lo tanto integra el soporte local y transnacional para las medidas de conservación. El estudio de la sobrestimación requiere atender el flujo transnacional de ideas y recursos

Paper submitted November 10, 2008; revised manuscript accepted March 16, 2009.

\section{8}


porque influyen en las interacciones de especies. Interdisciplinaria por naturaleza, la sobrestimación de especies atiende los retos políticos y económicos de la conservación porque reconoce a las diversas comunidades bumanas que moldean la supervivencia de la fauna silvestre en un sitio determinado. La sobrestimación de especies podría fomentar métodos de manejo y monitoreo más incluyentes socialmente enfocados a las demandas económicas, el comportamiento particular de las especies y las actividades bumanas en escalas locales.

Palabras Clave: África Central, antropología biológica, antropología cultural, antropología de conservación, comercio de vida silvestre, ecoturismo, especies sobrestimadas, gestión de la conservación, Gorilla gorilla, Loxodonta cyclotis

\section{Introduction}

We combined cultural and biological anthropology approaches in an analysis of the political, economic, ecological, and symbolic implications of tourism and other forest uses in the Dzanga-Sangha Dense Forest Reserve (RDS), Central African Republic (CAR). Alongside a growing number of anthropologists working on protected area management (West 2005; West \& Brockington 2006), we respond here to calls for "situated collaborations" connecting anthropological data and perspectives to conservation dilemmas (Brosius \& Russell 2003; Brosius 2006).

We describe how ideas about particular wildlife species as both economic and symbolic resources constitute "transvaluations" (i.e., species' economic, ecological, and symbolic importance) across cultural, economic, and geographical boundaries. Such transvaluations structure trade, tourism, and policy in the RDS area and shape species-specific variation in wildlife abundance and behavior in management zones. Transvaluation enables analysis of human communities beyond binding notions of local versus global and of animal communities in light of species-specific reactions to increasing human uses of wildlife habitat. We contextualize the ways varied human actors value wildlife, how those values are mediated by management practices and social inequality, and how they influence interactions with animals.

Transvaluation of species is applicable to different landscapes or animal species over time, as their meanings to various human actors change. Cross-cultural saliency is rooted in specific landscapes (Sanderson et. al. 2002) and is contingent on ecological and economic parameters; it makes some species more widely known in a given context than others. Gorillas (Gorilla gorilla gorilla) are central to tourism development within CAR and we investigated how transvaluation characterizes human relationships with them. We also considered forest elephants (Loxodonta africana cyclotis), which have long been exploited for meat, ivory, and trophies. These two wildlife species are most frequently viewed by tourists. Within RDS, chimpanzees (Pan troglodytes) have significance in the lore and ritual of forest foragers, or BaAka. Yet chimpanzees have long been scarce relative to go- rillas in this region. They have not generated the sort of iconic international cultural forms that gorillas have, from colonial travel sketches such as those in 1861 by Du Chaillu in which apes tower over tiny men to the film King Kong (Browne 2006). In our broader project, we considered such representations, but here, we focused on ethnographic and ecological research conducted over a 10 -year period in CAR.

Transvaluation of species integrates three axes inherent to human and wildlife interactions: transdisciplinary, transspecies, and transnational concerns within wildlife conservation. The concept of transvaluation captures the varying articulations between valuation of a species as political and economic (tourism and hunting revenues), as symbolic (translation and portrayal of wildlife knowledge across culture groups), and as ecological (dependent on hunting pressures or resource availability). It suggests approaches for further biocultural research on the patterns of animal forest use that make them accessible and significant to humans. Transvaluation bridges natural and social science work on conservation challenges, and moves beyond falsely dichotomized western versus other ways of thinking about wildlife. Here culturally distinct views of wildlife converged across communities such as indigenous groups of forest residents, elites, and international travelers. This convergence imbued particular wildlife species with powerful roles in how different humans imagine, use, and manage landscape. For example, elephants are key symbols of wilderness to donors, conservationists, and ecotourists, but they are also trophy targets for international clients of safari-hunting companies. These valuations produce distinct institutions and circuits for revenue flows internationally, nationally, regionally, or locally.

Rainforest residents hold divergent views of elephants' value as well. They are sources of ivory and meat for commercial hunters, restaurant owners, or merchants. Recent in-migrants to the area from northern plains decry elephant damage to crops and see them as obstacles to agrarian development. Longer-term residents, however, may have elephant totems that prevent them from hunting and consuming them; they may also earn cash, gifts, and the respect of foreign visitors whom they guide through 
the area. They see themselves as forging new relations of forest use that depart from brutal colonial trades or postcolonial political elites' appropriation of wildlife and related revenues. Although difficult to quantify, such varied valuations merit further attention from anthropologists and conservationists alike.

Describing details of how various humans interact with particular species can enable nonmarket values to be considered alongside the economics that dominate contemporary policy debates (logging and tourism revenues or bushmeat sales). Our study provides ecological and crosscultural nuance to debates about economic and ethical valuation of nature (Whittington 2002). At the same time, we offer a socially rich complement to calls to ascertain which species play key roles in ecosystem stability and perturbations (Ives \& Carpenter 2007). Finally we provide a cultural context for analysis of animal abundance and behavior, which enriches core conservation biology methods such as wildlife transect surveys by attending to impacts of hunting, observing, and habituating animals.

\section{Methods}

\section{Study Site}

Established in 1991, the RDS is co-managed as an integrated conservation and development project (ICDP) by the Central African government and World Wildlife Fund (WWF). Conservation efforts have focused on the Dzanga saline, a mineralized clearing that attracts wildlife, including up to 100 elephants at a time (Turkalo \& Fay 2001). The reserve's internal regulations designate the area around Dzanga as a core park sector for research and tourism. Beyond that core are buffer-zone sectors for community and safari hunting and logging. The uses of these sectors and the zoning plan itself reflect varied depictions of elephants and gorillas.

The RDS conservation management has struggled in the face of rising human pressures. The human population in the reserve has expanded from 1,000 in 1988 to a high of nearly 10,000 people in 2004 (WWF records). Human residents include agriculturalist and trading groups, attracted by the area's logging and conservation activities (also Whitemeyer et al. 2008), and longer-term resident fishing peoples and forest foragers, known locally as BaAka. Some BaAka work part time as research or tourist trackers. Guards are villagers and full-time employees. They carry firearms and wear uniforms, sources of status as well as social friction.

Cycles of selective logging have increased mammals' vulnerability to hunters, especially along logging roads (Blom et al. 2005; Laurance et al. 2006). Ecotourism, trophy hunting, and research also benefit from the road grid that links clearings that provide wildlife viewing and hunting opportunities (Noss 1998). We examined tourism and research as economic sectors that compete with logging and hunting and as activities that link symbolic transnational desires for access to animals with patterns of animal abundance and local residents' forest use.

We interpreted our results about how animal species and human groups use forest zones in the context of preexisting logging operations, in which conservation has created a parallel network of income generation and valuation of forests (Hardin 2000). Logging and trophyhunting revenues are paid to the Central African government; over time more revenues have been kept in regional rather than national coffers. Meat from safari hunting is seasonal and distributed locally, often disproportionately to local and regional officials, and is highly valued. Formal tourism and conservation revenues circulate through local nongovernmental organizations to fund small development projects, many of which were catalyzed by RDS as a means to offset conservation costs to residents. Informal tourism revenues tend to favor a few entrepreneurs with hostels or restaurants, many from other regions or even neighboring countries.

\section{Data Collection}

In 1997, to investigate how elephants and gorillas have responded to conservation efforts and human use, M.J.R. trained research teams of local conservation personnel, University of Bangui students, and BaAka trackers in ecological and transect methods. We (M.J.R. and research teams) surveyed $81 \mathrm{~km}$ of line transects of variable width and length (4-5 km) at varying distances from the main town of Bayanga. We categorized habitat type every $50 \mathrm{~m}$ along the $5-\mathrm{km}$ census transects that belonged to one of five habitat types. We noted wildlife, dung, and nests of all large mammal species and recorded all human traces and roads. When we found dung of the same species and age within a 5-m radius, we recorded it only once (Remis 2000). We mapped ape nests visible from the transects and assigned them to species (White \& Edwards 2000). Encounter rates of numbers of sign per kilometer surveyed have been widely used as estimates of abundance in the literature (Chapman et al. 2000), although caution is warranted because potential differences in visibility among transects can affect results. Within sites, relative encounter rates on transects are strongly correlated with density estimates of apes and elephants (Blake et al. 2005; Plumptre \& Cox 2006). Here we report on ecological data from our 2005 field season in which our census teams (managed by J. B. Kpanou) surveyed $148 \mathrm{~km}$ of $5-\mathrm{km}$ line transects in buffer zone and park sectors and contextualize it with data from previous seasons. We explored relationships and differences among habitat, park sector, wildlife, and human variables with SPSS (SPSS, Inc., Chicago, Illinois) Pearson's correlations and analysis of variance (ANOVA). 
In 1997, during 1-week stays at four different BaAka hunting camps within the transect areas, R.H. conducted semistructured interviews to collect life and work history information from BaAka (Bernard 2005). These interviews were conducted with R.H.'s trained team of University of Bangui students and three BaAka community researchers in French, English, Sango, Aka, or Gbaya languages. During an earlier (1995 and 1996) tourism study, R.H. and her research team focused on perceptions of risk, compensation, and communication across social and species barriers in 117 interviews with tourists, trackers, and guides. Most interviews were conducted after wildlife encounters to best reveal the ways that actual interactions challenge previously held stereotypes and expectations about wildlife and cross-cultural interactions (Dearden \& Harron 1994). We coded field notes on approximately $400 \mathrm{~h}$ of observed interactions between tourists, residents, and wild animals. Interviews were cross-checked and corroborated with participant observation, questionnaires were administered in person to tourist groups $(n=56)$, and conservation records were used to quantify earnings from trophy hunting and ecotourism.

Also in 1997 M.J.R. and R.H. collaborated to conduct focus-group research among locals, nationals, and international experts involved in research, logging, conservation, and community organizations. We gathered information about employment benefits and compensation across forest-use sectors, with follow-up by R.H. in 1999 and by M.J.R. in 2002 (Hardin \& Remis 2006). Across our study periods we also conducted ethnographic interviews and historical archival research at governmental and conservation offices in the CAR and Washington, D.C. and used colonial records housed at Aix en Provence in France to elucidate the use of elephants and gorillas in local traditions, storytelling, art work, and policy making (Hardin 2008). As part of a broader study on the trade in wild game in Bayanga, we collected ethnographic and interview data on the relative economic, ecological, and symbolic importance of gorilla and elephant meat in local markets (M.J.R., L. Daspit, and C. Jost, unpublished data).

\section{Results}

\section{Changing Wildlife Economies}

In Bayanga in the mid 1990s, formal revenues flowed through two distinct channels: trophy fees from safari hunters and stumpage fees from logging. These fees were controlled by regional and town officials and spent largely on infrastructure for their meetings and entertainment. Funds from the MacArthur Foundation and entry and rental fees from ecotourism were used by new, local nongovernmental organizations on agricultural, fishing, and hunting equipment and small-enterprise ventures (most of which failed). In 1995 monies flowing through these parallel circuits were approximately commensurate and constituted a significant resource by local standards. Trophy fees of US\$3680 went to the commune of Bayanga, and formal tourist revenue fees totaled $\$ 3078$ (Hardin 2000).

Subsequently, reserve policy raised fees for tourism, videotaping, and research to better match hunting and logging revenue generation. Nevertheless, formal revenues did not adequately capture tourism's benefits to RDS communities (Hardin 2000). In 1994-1995 nearly one-third of total tourism revenues were unaccounted for by project ledgers because they resulted from more informal tourist spending in the female-dominated sectors of restaurants and local markets (\$2475) or from tips and gifts to individual trackers or guides (\$1279). In 1997 logging, research, and conservation each hired comparable numbers of employees who received similar per capita annual incomes of approximately $\$ 1000$ (total of 1000 local employees across sectors) (Hardin \& Remis 1997). These various salaries and revenue streams from fees and taxes demonstrate how transvaluation can shape infrastructure, livelihoods, and economies at local and regional scales.

\section{Shifts in Symbolic Value}

Encounters with wildlife, whether for tourism or for research, provide opportunities for cross-cultural exchange of information. They also temporarily reconfigure status differences between BaAka guides, villager guards, and tourists because the latter rely on BaAka to detect animals and protect them from any dangers. Almost every tourist and many local residents who visit the reserve go to see the elephants at the Dzanga saline. Out of 56 tourist visits studied, 50 were to Dzanga. The trip requires visitors to walk $2 \mathrm{~km}$ on a busy elephant path and then cross a swampy stream to reach the elevated platforms at the clearing. Over half the individuals involved (68 out of 117 interviews) spontaneously professed connection, terror, humor, and wonder at the frequent interruption by elephants blocking the stream, which caused the visitors to become separated from their group as they fled or hid. In two groups interviewed, the tourists placed their small children in the arms of local guides for safety, indicating the magnitude of their own sense of risk or the lack of knowledge about the dangers of this complex setting. These intimate cross-cultural and cross-species interactions created social opportunities that redefined power relations and may explain why most interview respondents (72/117) expressed positive self-esteem and a sense of accomplishment following a trip to the Dzanga saline.

We explain forms of storytelling, dance, and mimicry of gorillas by conservation and research field staff elsewhere 
(Hardin \& Remis 2006). In our ethnographic interviews and archival research at colonial, government, and conservation offices, gorillas served as important icons of conservation across human communities, and original assessments of gorilla densities helped dictate land-use zoning in the original planning for RDS. Gorillas dominate the work of local artists participating in projectsponsored contests to develop promotional materials for the reserve. Such works include t-shirts, drawings, and a visually sophisticated poster that depicts gorillas as forests creatures, inhabitants in more "modern" spaces, and forest consumers. Nevertheless, in the RDS, dominant practice among various hunting peoples considers chimpanzees, but not gorillas, taboo for hunting (Hardin \& Remis 2006); gorilla meat is increasingly available for sale at the local Bayanga market (M.J.R. and L. Daspit, unpublished data).

\section{Integration of Ecological and Forest-Use Patterns}

Hunting and other interactions with animals for research or tourism were related to animals' use of humanmodified landscapes. In 2005 human sign was positively correlated with the percentage of secondary forest on transects $(r=0.358, n=31, p \leq 0.001)$ and abandoned elephant trails $(r=0.668, n=31, p \leq 0.001)$. Elephant dung was negatively correlated with proximity to Bayanga ( $r=-0.587, n=31, p \leq 0.003$ ), human $\operatorname{sign}(r=-0.765, n=31, p \leq 0.001)$, and percent roadside forest $(r=-0.387, n=31, p \leq 0.031)$. Gorilla sign was also negatively correlated with proximity to Bayanga $(r=-0.592, n=31, p \leq 0.001)$, but positively correlated with spent cartridges on transects $(r=0.505, n=$ $31, p \leq 0.004)$.

Transect data confirmed that tourist activity centered on elephant viewing and gorilla tracking in the Dzanga park sector. Net-hunting by locals (sometimes with tourists) and other subsistence and commercial hunting with snares and guns were concentrated in the Dzanga reserve buffer zone. Human sign in the reserve increased over time from a mean of $13.5 \mathrm{sign} / \mathrm{km}$ (SD 9.15) in 1997 to a mean of $32.3 \mathrm{sign} / \mathrm{km}$ (SD 9.11) in 2005 (ANOVA $F=$ $37.83, p<0.001$ ), whereas it did not change significantly in the park (1997: mean (SD) $=5.5 \mathrm{sign} / \mathrm{km}$ [1.97], 2005: mean $(\mathrm{SD})=4.83 \mathrm{sign} / \mathrm{km}[1.89])$. Wire snares were more common in reserve than in park sectors; however, in 2005 we found guns and discarded elephant carcasses on transects in the remote southern park sector.

A consistent presence of researchers and tourists has deterred but not eliminated poaching at the Dzanga clearing (Turkalo \& Fay 2001). In the early- to mid-1990s, we, and our informants, often encountered elephants in the fields and the town in Bayanga, but elephants appeared to have declined. Carroll (1986) reported an average of 8.15 dung piles $/ \mathrm{km}$, whereas we found 2.33 elephant dung piles/km on transects in 1997 (Remis
2000) and only 1.39 dung piles/ $\mathrm{km}$ in 2005. In 2005 in hunted zones, elephants were scarce, dung encounter rates were too low to calculate densities (2005 elephant dung piles $/ \mathrm{km}$ : park $=3.81$, reserve $=0.09$ ) (also Blake et al. 2007), and herbs were taking over elephant trails (abandoned elephant trails park vs. reserve $t=4.367$, $p<0.001)$.

Gorillas were more elusive than elephants on our transects at RDS as well as for tourists and researchers trying to observe them, but they were not as heavily hunted for international trade (Daspit et al. 2009). Our transect data suggest that the Bai Hokou Gorilla Tourism and Research Center at RDS since the late 1980s has served as a buffer to the encroachment of hunting in the immediate area. In 2005 in RDS, there was a mean of 1.76 individual gorilla nests $/ \mathrm{km}(n=252$ nests) and 0.50 group nest sites $/ \mathrm{km}$ ( $n=71$ group nest sites), which is similar to our 1997 results (Remis 2000). Nevertheless, gorilla vulnerability within RDS increased with distance to human population centers. Nest encounter rates were lowest in the busy safari-hunting and artisanal diamond zone, where group size is also the lowest (Remis \& Hardin 2007). The size of gorilla nest groups averaged more than five nests in the mid 1980s through the early 1990s (Carroll 1986) and was 4.7 in 1997 (Remis 2000), but fell in 2005 to 3.21 in the park and 2.7 in the reserve ( $n=138$ nests) and was reported as 2.7 by Blake et al. (2005).

\section{Discussion}

Our combined ecological and ethnographic data suggest nuanced behavior by elephants and gorillas relative to watersheds, logging-related resource availability, and human activities. Wildlife species responded to human actions beyond subsistence or economic activities, including observation, habituation, protection, and play. We observed that experienced trackers incite monkeys to violence and herd groups of forest hogs for the fun of it. Such complex cross-species interaction highlights the importance of considering the ecological, economic, and symbolic dimensions of the multiple activities associated with conservation and development of extractive and nonextractive forest resources.

Elephants have historically had a complex relationship with humans across Africa (Lee \& Graham 2006). In our study region they migrate remarkable distances to visit the Dzanga saline (Blake et al. 2007). After initial implementation of the reserve, locals complained about increased elephant activity, yet recent surveys show a decline in elephant abundance around Bayanga (Remis \& Hardin 2007) and that distance from logging roads is a major influence (Blom et al. 2005; Blake et al. 2007). When evaluating the effectiveness of conservation, increased elephant vulnerability within the cores of protected areas is troubling. Recent surveys detected elephant carcasses 
and poaching camps around Dzanga, where elephant abundance is highest (Blake et al. 2007). Southern CAR and Cameroon have been implicated as sources for the international illicit trade in ivory (Courouble et al. 2003), and in 2008 TRAFFIC opened an office in Cameroon to deal with the increase in trafficking in the Sangha TriNational Park (http://www.traffic.org). Furthermore, anecdotal reports by residents, tourists, and researchers of aggressiveness of elephants in the core at RDS also suggest that elephant vulnerability may have increased. Such aggression is disturbing because for conservation to be successfully implemented, basic safety must be assured for wildlife, local populations, staff, and tourists alike through effective protection.

Recent work describes how the behaviors and migration patterns of elephants are disrupted by social trauma (Bradshaw et al. 2005; Siebert 2006). This prompted us to question the absence of elephants from reserve sectors in 2005, where Gilbertiodendron dewevrei forest was in mast fruit and should have led them there (Blake \& Fay 1997). As reports of elephant trauma in East Africa illustrate, these animals are more than targets of bushmeat or tourist trades. They engage in highly complex interactions with humans, exchanges that mark not only human memories and behaviors but also those of these animals themselves. The fact that humans and elephants consistently manage to co-occupy the forest trails around the Dzanga clearing with few instances of injury is remarkable, given the increasing hunting and other conflicts between humans and elephants in buffer zones at RDS.

For trackers and guides, interpersonal benefits couple with informal revenues to counterbalance feelings of anger, loss of access to the wildlife-rich area for subsistence activities, and tensions over the distribution of benefits. In contrast, BaAka elders in hunting camps commented on increases in overall human population and roads and the availability of firearms. They have diversified their livelihood strategies to include working for loggers, researchers, and tourists, but are concerned with the variation in tourist flows, violence of antipoaching patrols, and ever-scarcer game because of increasing competition with those with newer hunting technologies.

Gorillas may be especially likely to coexist with humans where research and tourism efforts focus awareness on them (Sicotte \& Uwengeli 2002). Nevertheless, proximity to hunters at RDS is risky, as suggested by the declines in the size of gorilla groups and recent increases in gorilla meat at the local market in Bayanga (Daspit et al. 2009). Vulnerability even within protected areas exacerbates the consequences of threats of Ebola and other diseases for gorilla populations as a whole (Bermejo et al. 2006).

Giles-Vernick and Rupp (2006) argue that narratives about great apes show how "Africans have depicted and debated social differences, social tensions, and relations between self and others. . .and. . .highlight the nature of their engagements with external processes, resources, and people." Our results place such insights in the context of ecological change and forest management. Our data on gorilla abundance (Remis 2000) suggest that their use of forest microhabitats in the wake of selective logging, and perhaps in combination with human fascinations with them, has enabled at least temporary adaptation to increasing human forest uses. Although many species decline with logging (Chapman et al. 2000), gorilla sign is often concentrated in recently logged zones that are not only temporarily herb rich (Remis 1997; Malcolm \& Ray 2000) but also filled with human activity and snares (Remis \& Hardin 2007). Our 1997 gorilla encounter rates and density estimates (Remis 2000) were markedly similar to those recorded by Carroll in 1986 and the Monitoring the Illegal Killing of Elephants (MIKE) in 2003-2004 (Blake et al. 2007), although group sizes were not, and current indications lead us to now predict declines in density. Further work is needed to ensure gorillas' continued persistence despite increasing human pressures.

Unlike elephants at RDS, gorillas are not a predictable attraction. Only $7 \%$ of tourist expeditions that R.H. monitored as tracking gorillas in the park sector ever found any gorillas, although the excitement of searching mitigated tourist disappointment. Greer and Cipolletta (2006) report that only 700 tourists tracked gorillas at Bai Hokou between 1998 and 2006. In this dense forest most gorillas remain fearful of humans; only two tourists interviewed in the mid 1990s before gorillas were fully habituated at Bai Hokou obtained a clear view of gorillas. The current relative ease of tourist gorilla observation there (Kristof 2006) is testimonial not only to the long-term work on habituation but also to how transvaluation of these animals by both locals and nonlocals creates the context for such success. These intersecting and changing values for wildlife should inform more fluid management mechanisms.

\section{Conclusions}

Pressures on wildlife and other natural resources in the Western Congo Basin have escalated during a period of economic and political instability in the past 15 years. The confluence of logging and conservation activities may foster concentrations and habituation of elephants and gorillas that render them more vulnerable to volatile poaching dynamics. Moreover, social conflict has cropped up when conservation programs have had difficulties in achieving multiple human needs, poverty alleviation, and biodiversity conservation goals (Oates 1999; Newmark \& Hough 2000). Some of these tensions can be seen in the RDS project's repeated failure to give credit to local communities for their conservation successes. 
Yet many reserve residents value wildlife beyond the nutritional or material gain, from the BaAka who track animals to the villager guides who translate the forest for French soldiers or wealthy tourists. For conservation to effectively engage dynamic valuations of wildlife, they must be linked to actual ecological outcomes. One testable interpretation that emerges from our ethnographic interviews is that gun hunters moving through gorilla-rich, recently logged zones may in fact be systematically avoiding targeting gorillas because of their high profile at RDS. Although the ability of gorilla tourism to underwrite conservation efforts has been debated (Butinski \& Kalina 1998), at RDS, the very idea of their presence seems a crucial support to conservation and continued tourist visits. Transvaluation, in terms of social dialogue about specific species across various human-use groups, could help conservation management move beyond mere zoning to better respond to the kinds of social, economic, and environmental fluidity described here.

At such local scales, if wildlife conservation in situ is to flourish, awareness of transcultural valuation processes must infuse the methods and rhythms of the everyday in protected areas. Broadening debates about how a species might be designated as transvalued could give rise to dialogue within management areas and lead to more concrete and cross-culturally salient terms on which to engage residents of protected areas in communitybased, adaptive conservation management (Berkes \& Folke 1998). Community decisions to enforce spatial or temporal hunting bans, if well informed by research, could temper a growing sense of alienation from wildlife as a resource by residents who comply with contemporary zoning, legal, and policy frameworks.

In an era of increasingly integrated and intensive international consumption of forests and their resources, communities are crucial to the monitoring and managing of forests (Agrawal 2005). In Bayanga in-migrants, longer-term residents, and foreign staff are building fragile relationships with one another that can founder on debates about zoning, competing forest use, or ethnically based subsistence categories. Yet wildlife conservation can either exacerbate or alleviate such tensions. Integrative transvaluation complements the rival circuits described above for extractive and conservation-based activities. For tourists, trophy hunters, logging clients, and local-community participants alike, the trip to the Dzanga clearing to see elephants is popular. The journey serves as a ritual that suspends the social boundaries of normal life and often involves circumstances of danger, pain, or reversal of social roles after which "normal" life resumes (Turner 1969).

Effective rituals can serve to create membership in a particular community or society and strengthen, purify, or cure their participants who then reenter their active lives. The unpredictability of human-animal encounters and interpersonal interactions at Dzanga confer on participants a new appreciation of each other and of local ecosystems. The transvalued species concept acknowledges the saliency of new forms of community, from research teams living together in forests to tourists such as those who provided the new basketball court on which Bayanga's youth now play.

At international scales, transvaluation provides opportunities for dialogue across the increasingly polarized positions of advocacy of either human or animal rights (Sanderson \& Redford 2003; Robinson 2006; Bennett et al. 2007). It grounds such debates in empirical investigation of how economic and policy practices combine with ecological factors to shape circumstances of animal abundance, inviting us to consider more deeply the roles of animals as both actors and symbols in new economies and cultural practices of forest use.

The Dzanga clearing has become more than a core zone for the maintenance of elephant populations; it is a site where humans and wildlife effectively maneuver around each other, creating new interspecies and intercultural relations of forest use. Such precarious accomplishments of transvaluation should not go uncelebrated when they succeed or unlamented when they fail. They are beacons from forest communities whose interactions with industry and conservation reveal cosmopolitan cultural ecologies that enable varied and dense human interactions with wild animals no longer found elsewhere.

\section{Acknowledgments}

We thank RDS and the CAR government for permission to conduct the study. J. B. Kpanou managed transect teams and B. Bokoto De Semboli provided logistical support in 2005. H. Zana, E. Télé, B. Dimali, K. Adamson, E. Wonga, J. P. Nyele, and P. Mokedi assisted in data collection. We thank A. Agrawal, K. Redford, and reviewers for comments. We acknowledge support from the National Geographic Society (7873-05), Purdue University, the University of Michigan, the Harvard Academy for International and Area Studies, and World Wildlife Fund.

\section{Literature Cited}

Agrawal, A. 2005. Environmentality: technologies of government and the making of subjects. Duke University Press, Durham, North Carolina.

Bennett, E.L., et al. 2007. Hunting for consensus: reconciling bushmeat harvest, conservation, and development policy in West and Central Africa. Conservation Biology 21:884-887.

Berkes, F., and C. Folke. 1998. Linking social and ecological systems: management practices and social mechanisms for building resilience. Cambridge University Press, New York. 
Bermejo, M., J. D. Rodríguez-Teijeiro, G. Llera, A. Barroso, A. Vilà, and P. D. Walsh. 2006. Ebola outbreak killed 5000 gorillas. Science 314:1564.

Bernard, R. 2005. Research methods in anthropology: qualitative and quantitative approaches. Altamira Press, Walnut Creek, California.

Blake, S. 2005. Long-term system for monitoring the illegal killing of elephants (MIKE). Central African forests: final report on population surveys 2003-2004. Wildlife Conservation Society, Washington, D.C. Available from http://www.cites.org/common/prog/mike/ survey/central_africa_survey03-04.pdf (accessed February 2009).

Blake, S., and J. M. Fay. 1997. Seed production by Gilbertiodendron dewevrei in the Nouabale-Ndoki National park, Congo, and its implications for large mammals. Journal of Tropical Ecology 13:885891.

Blake, S., et al. 2007. Forest elephant crisis in the Congo Basin. Public Library of Science Biology DOI: 10.1371/journal.pbio.0050111.

Blom, A., R. van Zalinge, I. M. A. Heitkonig, and H. H. T. Prins. 2005. Factors influencing the distribution of large mammals within a protected central African forest. Oryx 39:381-388.

Bradshaw, G. A., A. N. Schore, J. L. Brown, J. H. Poole, and C. J. Moss. 2005. Elephant breakdown. Nature 433:807.

Brosius, P. 2006. Common ground between anthropology and conservation biology. Conservation Biology 28:683-685.

Brosius, P., and D. Russell. 2003. Conservation from above: an anthropological perspective on transboundary protected areas and ecoregional planning. Journal of Sustainable Forestry 17(1/2):39-65.

Browne, J. 2006. Science in culture: a bigger picture of apes. Nature 439:142.

Butinski, T. M., and J. Kalina. 1998. Gorilla tourism: a critical look. Pages 294-313 in E. J. Milner-Gulland and R. Mace, editors. Conservation of biological resources. Blackwell, Oxford, United Kingdom.

Carroll, R. W. 1986. The status, distribution and density of Gorilla and Loxodonta africana cyclotis in southwestern Central African Republic. MS thesis. School of Forestry, Yale University, New Haven, Connecticut.

Chapman, C., S. R. Balcolmb, T. R. Gillespie, J. R. Skorupa, and T. T. Struhsaker. 2000. Long-term effects of logging on African primate communities: a 28-year comparison from Kibale National Park, Uganda. Conservation Biology 14:207-217.

Courouble, M., F. Hurst, and T. Milliken. 2003. More ivory than elephants: domestic ivory markets in three West African countries. TRAFFIC International, Cambridge, United Kingdom.

Daspit, L. D., C. Jost, and M. J. Remis. 2009. Primate conservation in central African forests: combined ethnographic and ecological approaches. American Journal of Primatology 71: in press.

Dearden, P., and S. Harron. 1994. Alternative tourism and adaptive change. Annals of Tourism Research 21:81-102.

Du Chaillu, P. 1861. Exploration and adventures in Equatorial Africa. John Murray, London.

Giles-Vernick, T., and S. Rupp. 2006. Visions of apes, reflections on change: telling tales of great apes in Equatorial Africa. African Studies Review 49:51-73.

Greer, D., and C. Cipolletta. 2006. Western gorilla tourism: lessons learned from Dzanga-Sangha. Gorilla Journal 33: http://www. berggorilla.org/english/gjournal/texte/33dzanga.html.

Hardin, R. 2000. Translating the forest: tourism, trophy hunting, and the transformation of forest use in southwestern Central African Republic. PhD dissertation. Department of Anthropology, Yale University, New Haven, Connecticut.

Hardin, R. 2008. Toward an ethic of Intimacy: touring and trophy hunting for elephants in Africa. Pages 419-448 in C. Wemmer and C. A. Christen, editors, Elephants and ethics: toward a morality of coexistence. Johns Hopkins University Press, Baltimore, Maryland

Hardin, R., and M. J. Remis. 1997. Research and rural development work sessions: Bayanga, RCA, July 31-August 2, 1997. Sangha
River Network, New Haven, Connecticut. Available from http:// www.yale.edu/sangha/resource/RES_SET.html (accessed February 2009).

Hardin, R., and M. J. Remis. 2006. Biological and cultural anthropology of a changing tropical forest: a fruitful collaboration across subfields. American Anthropologist 108:273-285.

Ives, A., and S. R. Carpenter. 2007. Stability and diversity of ecosystems. Science 317:58-62.

Kristof, N. 2006. Where the gorilla and the antelope play. New York Times, 26 September. Available from http://kristof.blogs. nytimes.com/2006/09/19/finding-eden/ (accessed April 2009).

Laurance, W. F., B. M. Croes, L. Tchignoumba, S. A. Lahm, A. Alonso, M. E. Lee, P. Campbell, and C. Ondzeano. 2006. Impacts of roads and hunting on central African rainforest mammals. Conservation Biology 20:1251-1261.

Lee, P. C., and M. D. Graham. 2006. African elephants and humanelephant interactions: implications for conservation. International Zoo Yearbook 40:9-19.

Malcolm, J., and J. C. Ray. 2000. Influence of timber extraction routes on Central African small mammal communities, forest structure and tree diversity. Conservation Biology 14:1623-1638.

Newmark, W. D., and J. L. Hough. 2000. Conserving wildlife in Africa: integrated conservation and development projects and beyond. BioScience 50:585-592.

Noss, A. 1998. The impact of cable snare hunting on wildlife populations in the forests of the Central African Republic. Conservation Biology 12:390-398.

Oates, J. F. 1999. Myth and reality in the rain forest: how conservation strategies are failing in West Africa. University of California Press, Berkeley, California.

Plumptre, A. J., and D. Cox. 2006. Counting primates for conservation: primate surveys in Uganda. Primates 47:65-73.

Remis, M. J. 1997. Western lowland gorillas as seasonal frugivores: use of variable resources. American Journal of Primatology 43:87109.

Remis, M. J. 2000. Preliminary assessment of the impacts of human activities on gorillas: Gorilla gorilla and other wildlife at DzangaSangha Reserve, Central African Republic. Oryx 34:56-65.

Remis, M. J., and R. Hardin. 2007. Assessment of forest use patterns and wildlife abundance: coupling anthropological and ecological approaches. Pages 85-109 in K. Hanna, D. Clark, and S. Slocombe, editors. Protected areas management: policy and design. Spon Press, Routledge, United Kingdom.

Robinson, J. 2006. Conservation biology and real world conservation. Conservation Biology 20:658-669.

Sanderson, S. E., and K. H. Redford. 2003. Contested relationships between biodiversity conservation and poverty alleviation. Oryx 37:389-390.

Sanderson, E.W., K. H. Redford, A. Vedder, P. B. Coppolillo, and S. E. Ward. 2002. A conceptual model for conservation planning based on landscape species requirements. Landscape and Urban Planning 58:41-56.

Sicotte, P., and P. Uwengeli. 2002. Reflections on the concept of nature and gorillas in Rwanda: implications for conservation. Pages 163182 in A. Fuentes and L.D. Wolfe, editors. Primates face to face. Cambridge University Press, Cambridge, United Kingdom.

Siebert, C. 2006. An elephant crackup? New York Times Magazine, 8 October. Available from http://www.nytimes.com/ 2006/10/08/magazine/08elephant.html (accessed June 2009).

Turkalo, A., and J. M. Fay. 2001. Forest elephant behavior and ecology. Pages 207-213 in W. Weber, L. White, A. Vedder, and L. Naughton, editors. Conservation and ecology of an African rain forest. Yale University, New Haven, Connecticut.

Turner, V. 1969. The ritual process. Aldine, Chicago, Illinois.

West, P. 2005. Translation, value, and space: theorizing an ethnographic and engaged environmental anthropology. American Anthropologist 107:632-642. 
West, P., and D. Brockington. 2006. An anthropological perspective on some unexpected consequences of protected areas. Conservation Biology 20:609-616.

White, L. J. T., and A. Edwards. 2000. Conservation research in the African rain forest: a technical handbook. Wildlife Conservation Society, New York.
Whitemeyer, G., P. Elsen, W. T. Bean, A. Coleman, O. Burton, and J. S. Brashares. 2008. Accelerated human population growth at protected area edges. Science 321:123-126.

Whittington, D. 2002. Improving the performance of contingent valuation studies in developing countries. Environmental and Resource Economics 22:323-367.

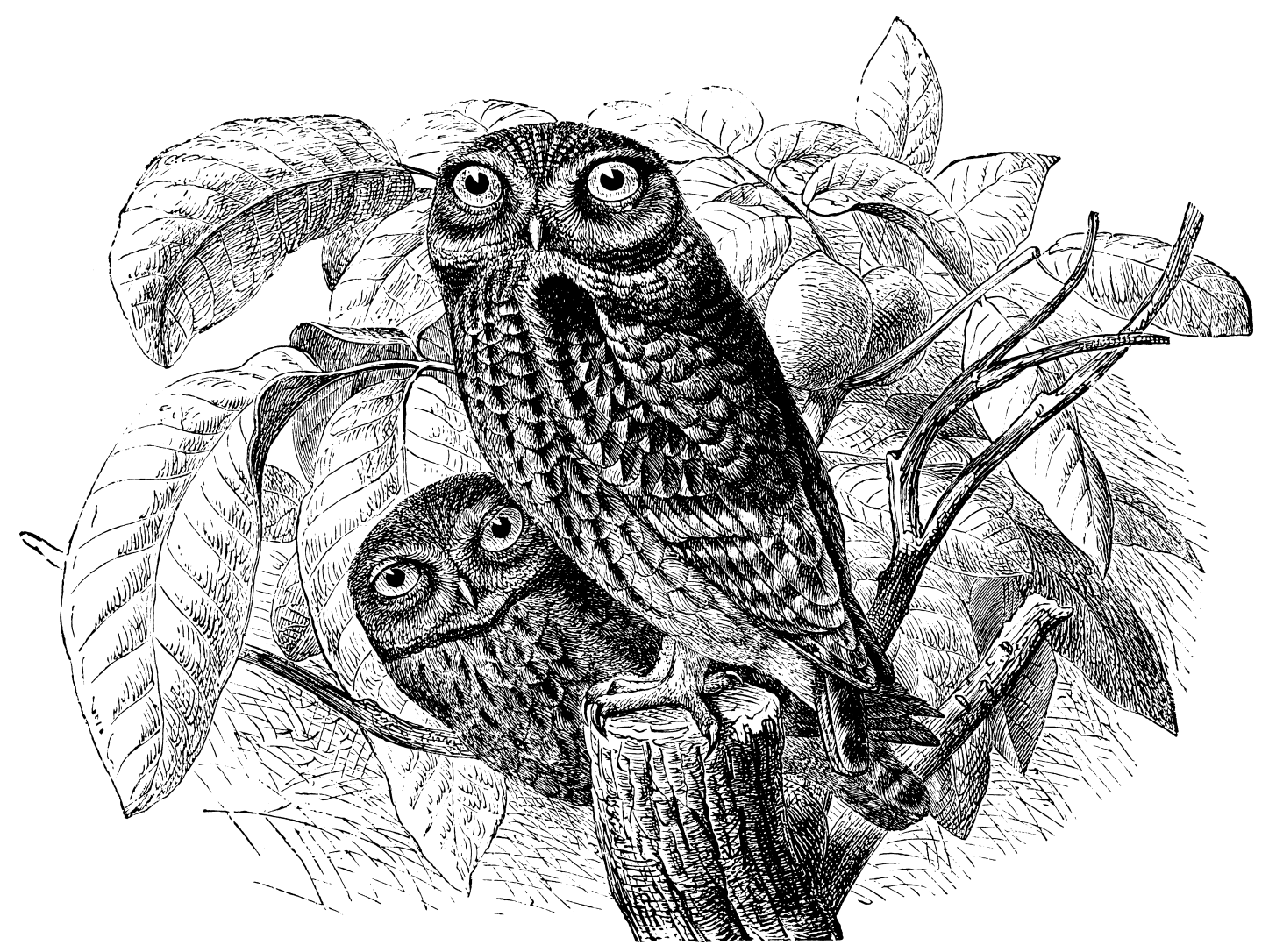

